\title{
Exploring the Managerial Perspectives of Banking Industry Towards Consumer Empowerment: A Study in Banking Industry
}

\author{
Bassam Sahibzada Iqra Rahim Muhammad Saad Ziker Sidra Shaukat Talal Anjum \\ Scholars at Shaheed Zulfiqar Ali Bhutto Institute of Science \& Technology
}

\begin{abstract}
This study aims to explore and extract the managerial perspective of banking industry towards consumer empowerment. This is an emerging and growing phenomenon that has multiple dimensions and implications for the stability of consumers, financial sector as well as economy. Moreover, it is also one of the latest objectives of State Bank of Pakistan. Thus, this study aims at fulfilling the gap of local context by catering the supply side perspective along with methodological gap as most of the researches conducted globally related to this topic are quantitative while this research will be qualitative in nature.

It is a mono method study i.e. qualitative based on exploratory strategy which focuses on in-depth knowledge and understanding of the managerial insights about the concept of consumer empowerment in banking sector such as its importance, current scenario, benefits, impediments etc. The sampling method that has been used is non probability purposive sampling. Primary data has been collected through interview protocol which was adopted and modified. The validity of the interview protocol has been checked through face validity which includes approval by research and domain expert. The interviews were conducted till saturation point and after conducting the interviews, the data was analyzed through content analysis i.e. by coding sorting and sifting. The reliability of the research has been checked through member checking and triangulation.

The findings of this study indicate the initiatives, status and prospects of consumer empowerment particularly through financial literacy and digitalization in the banking sector of Pakistan. Different dimensions of consumer empowerment have been discovered along with its benefits not only for the consumers but for banks as well. Moreover, this study also enlightens the techniques to gauge effectiveness of these initiatives, the challenges hindering the motives and implementation, the regulatory stance as well as the future prospects.

This significance of this study lies in the fact that consumer empowerment is an emerging trend and need in our banking sector upon which the regulator is dynamically working and therefore seeking for the outlook of banks. Thus, the obtained information can be used by regulator to understand the perspective of banking sector towards consumer empowerment. Moreover, the findings can also be used by banks and other financial institutions as it would aid them in planning and execution of initiatives by indicating the avenues that can be tapped.
\end{abstract}

DOI: $10.7176 /$ RJFA/11-15-05

Publication date:August $31^{\text {st }} 2020$

\section{INTRODUCTION}

\subsection{Background of the Study}

It has been precisely delineated by Wang (2012), "When you focus on the consumer, the consumer responds". This is because with the rapidly growing dynamics of the world, there has been a shift from passive consumer to an empowered consumer who possesses greater access, alternatives, platforms and opportunities (Rosenbaum, 2015). Consumer empowerment refers to giving consumers power through resources such as greater information, options and tools which facilitate decision-making and allow them to tailor a product as per their own specifications. This can be done by spreading greater awareness and education among consumers along with protecting their rights to ensure that they make optimal utilization of their financial resources. Moreover, the consumers must be provided novel solutions that can empower them by enhancing the domain of their opportunities like through digitalization and technological advancements (Bauhaus, 2013).

The financial sector, in particular the banking industry has been experiencing swift progressions globally. After the financial crisis of 2008, various initiatives have been incorporated to empower the consumers in order to safeguard them from the detrimental consequences of bad financial decisions. Therefore, the concept of consumer empowerment is constantly gaining prominence in the financial sector. Globally, the banking sector of various countries such as USA, Malaysia, Europe etc. are embarking various initiatives like educational tools including games, websites, training sessions, workshops etc. through which awareness and financial literacy are being augmented. Younger generation is being targeted in particular to instill the practice of vigilant monetary management at a younger age (Week, 2015). Furthermore, the regulators and consumer associations of these countries have made it compulsory for banks to inculcate the initiatives aimed at empowering consumers through greater financial education and financial literacy. Apart from this, these countries have incorporated strict adherence to consumer protection rights in the financial sector to cater the disparity of information between consumers and financial service providers and to ensure that consumers don't fall a prey to deceptive practices (Ardic \& Ibrahim, et. al, 2011). Moreover, these initiatives are also beneficial for the banks as they lead to their 
promotion along with augmenting their customer satisfaction and loyalty which in turn benefits their business in terms of profitability (Hunter \& Garnefeld, 2011).

While the concept of consumer empowerment is flourishing rapidly worldwide, this concept is not much refined in Pakistan particularly in the banking sector. The consumers aren't much empowered due to major lacking in financial literacy and rights which subsequently creates obstacles in promoting financial inclusion in the country. The current statistics by The Access to Finance Survey (A2FS) depict that only thirteen percent of adults in Pakistan have formal financial accounts. In addition, around forty percent of the population that is financially excluded stated inappropriate knowledge of financial services as the key reason for being financially excluded and rather uses informal means (Susan \& James Manyika, et. al, 2016). This low level of financial inclusion has led to adverse consequences for sustainable growth and poverty alleviation. Therefore, empowering consumers through greater financial knowledge of basic as well as innovative and digital products/services can aid in tackling financial exclusion and can benefit the entire economy by building financial capability of the people (Anwar, 2012). However, the dilemma is that in Pakistan the banks aren't conducting many independent initiatives to accelerate this concept.

Thus, this study aims to do an in-depth qualitative analysis of the role and outlook of banking industry from managerial perspective on the emerging trend of consumer empowerment. The significance of this study lies in the fact that consumer empowerment is an extremely vital concept that is needed to ensure the stability of financial markets and prosperous economy. The regulator of banks in Pakistan i.e. State Bank of Pakistan (SBP) is taking various initiatives to promote consumer empowerment and is also encouraging banks to take independent initiatives. Therefore, valuable insights will be attained that will highlight the scenarios, obstacles etc. from the perspective of banks about this concept which can be shared with the State Bank of Pakistan as it is one of their objective upon which they are actively working (Ahmad, 2016).

\subsection{Problem Statement}

How managers in banking industry of Pakistan perceive about emerging trend and implications of consumer empowerment?

The purpose of this study is to explore the perception of banking industry's managers on the emerging trend of consumer empowerment through in-depth analysis of managerial insights. This study aims at digging out valuable insights about concept of consumer empowerment in banking sector such as its importance, need, current scenario, benefits, impediments etc. Moreover, the information can be helpful for The State Bank of Pakistan in designing the components of its policies and strategies that are aimed at accelerating consumer empowerment (Ahmad, 2016).

\subsection{Research Questions}

1) What is the current scenario of consumer empowerment in banking industry from manager's view, including the types of initiatives undertaken by banks for various segments?

2) What are the needs, importance and prospects of consumer empowerment in the banking sector of Pakistan?

3) What are the persisting impediments faced by banks in the implementation of consumer empowerment?

4) What managers think about technology and digitization in empowering consumers?

5) Do consumer empowerment initiatives influence the performance, publicity and goodwill of the banks?

\subsection{Research Objectives}

1) To determine the current scenario of consumer empowerment in banking industry, including the types of initiatives undertaken by banks for various segments

2) To explore the need, importance and prospects of consumer empowerment in banking sector

3) To dig out the persisting impediments faced by banks in the implementation of consumer empowerment

4) To explore the influence of consumer empowerment initiatives on performance, publicity and goodwill of the banks

5) To identify the motives of bank managers regarding executing of technology and digitalization in empowering consumers

\subsection{Significance of the Study}

This study holds significance because consumer empowerment is an emerging trend upon which the regulators are dynamically working so that it can be inculcated profoundly in Pakistan as well just like it is being flourished globally. This trend is gaining prominence because empowering consumers through greater awareness, protection, financial knowledge etc. benefits the banks as well as the entire economy along with consumers. Therefore, this study would delineate fruitful insights on consumer empowerment by exploring the perception, current scenario, outlook etc. of banking sector from managerial perspective. The obtained information can be beneficial for the State Bank of Pakistan in designing its consumer empowerment policies and strategies as they are seeking for the 
outlook of banks and determining ways through which banks can be encouraged to embark independent initiatives to promote this concept (Ahmad, 2016).

\subsection{Research Limitation}

Due to limited resources, i.e. time constraint and budget constraint; the study would not be able to take into account to vast area and wider population. Also, specialized tools cannot be used for analyzing the data due to budget constrictions. Research data cannot be gathered from other cities due to lack of accessibility. Above all, the nature of this study (qualitative) prohibits generalization of results to wider population, other situations and geographic locations. Moreover, inadequate literature on the concerned concept is also one of the limitations. In addition, managers might feel hesitant in sharing their perceptions and opinions or might not provide sufficient time which can also restrict the extent of research.

\subsection{Research Justification}

This study would enlighten valuable insights about the emerging trend of consumer empowerment in banking industry through managerial perspective. The concept of consumer empowerment is getting prominence globally as well as in Pakistan since it strengthens the financial service sector and promotes sustainable economic growth through enhancing financial inclusion. This is because it equips consumers with the knowledge, protection and skills which promote their financial wellbeing. Moreover, efforts initiated by banks aimed at empowering consumers, also helps them in augmenting their goodwill and public relations. Thus, it is a lucrative topic as the obtained information can be beneficial for financial institutions and State Bank of Pakistan in developing effective strategies and policies of consumer empowerment.

\subsection{Research Scope}

The study aims at extracting the perception of managers in banking industry about the rising trend of consumer empowerment. Due to the persisting limitations, the scope of the research is that it would be conducted from managers of the registered banks that fall within the legal ambit of State Bank of Pakistan operating in Karachi only. Moreover, it would include those managers who have knowledge in the required domain.

\subsection{Assumptions}

The research will be conducted with assumption that data provided by respondents is authentic and accurate as far as possible. Furthermore, it will also be assumed that trends are constant throughout the course of research and managers who will be interviewed for this study are aware of concerned concept and will provide entire information about their perception.

\subsection{Definitions of Key Terms}

\subsubsection{Consumer Empowerment}

Consumer empowerment refers to giving consumers power through resources such as greater information, understanding, options, tools and resources that facilitate them in decision-making (Bauhaus, 2013).

\subsubsection{Financial Literacy}

According to Remund (2010), financial literacy depicts capability of a person to comprehend financial aspects. Huston (2010) thinks about financial literacy as an individual's knowledge about financial instruments along with their application in personal as well as professional life. Financial literacy comprises of the ability to manage and handle financial matters such as a bank account, budget, savings, investments, debt management etc. (Clarke, 2015).

\subsubsection{Financial Education}

It is the process by which financial consumers/investors develop their understanding of financial matters such as financial products/services, risk analysis, alternatives of financing etc. This capability is built through education in terms of information, instructions and knowledge that aids individuals in excelling their financial skills. It augments their financial wellbeing by enabling them to make sound financial decisions through informed choices and better evaluation (Clarke, 2015).

\subsubsection{Empowerment}

It refers to diminishing impediments for market participation/involvement by improving the accessibility of relevant information (Williams, 2011).

\section{LITERATURE REVIEW}

\subsection{Consumer Empowerment}

Consumer empowerment is a phenomenon that has various implications, meanings and dimensions. However, more precisely it refers to providing consumers power through resources such as greater information and options that facilitate them in making optimal decisions. (Bauhaus, 2013). 
Education/information and choices are the two most vital dimensions of consumer empowerment as they lead to more informed decisions through better understanding which enables the consumers to exercise best alternatives (Broniarczyk \& J.G.Griffin, 2014).

Another aspect of consumer empowerment is providing consumers channels and opportunities through which they can get more power to voice out their opinions and complaints. Similarly, consumers are empowered through superior choices that can make things simpler and convenient for them and therefore an increasingly relevant trend of digitalization is playing vital role in empowering consumers through enhancing expediency, exposure, swiftness in operations along with providing consumers with vocal forums (McShane \& Sabadoz, 2015).

\subsection{Need of Consumer Empowerment in Financial Sector}

The trend of empowering consumers in the financial sector has gained immense significance globally particularly in the banking sector as it has undergone rapid progressions. After the financial crises of 2008, a critical need for greater consumer empowerment was observed in the financial sector as the crises left many consumers financially devastated. Thus, various initiatives were embarked to safeguard the consumers against detrimental consequences of wrong financial decisions (Week, 2015)

Consumer Empowerment is needed to ensure stability of financial market and for a prosperous economy. This is because when consumers are empowered through greater alternatives, platforms and financial knowledge/awareness, they are able to make better financial decisions. Moreover, to ensure that financial markets are deep and serve the broad population and financial inclusion is high, the consumers must be empowered through financial education, greater opportunities/choices and protection measures so that their trust in financial institutions increases and they can be a part of formal financial channels (Clarke, 2015).

Financial education reduces financial vulnerability among individuals and also aids them in learning about novel technological solutions that can make their lives better. However, along with education and technological solutions, consumers must be protected through well designed system as would encourage and allure them to get financially included (Atkinson \& Messy, 2013)

\subsection{Need of Consumer Empowerment in Banking Sector of Pakistan}

In Pakistan, the direst need for consumer empowerment persists due to lack of financial inclusion as compared to other countries with similar levels of income and development. This also acts as an obstacle in sustainable growth and poverty mitigation of the country. According to statistics, only thirteen percent of Pakistani adults have a formal account. Similarly, financial literacy and capability in Pakistan is very low due to lack of knowledge about financial products (Pasha, 2016). Although, the saving rate is comparatively less in Pakistan yet more than half of the adult population saves but uses informal means to do so in which the share of females is further less. This clearly indicates that empowering consumers through financial education is a specific area that needs to be addressed to tackle financial exclusion (Anwar, 2012).

Thus, in the banking sector of Pakistan empowerment of consumers particularly through financial education is very important as this is a major area where lacking exists. Moreover, the consumers should be empowered through digitalized solutions and simultaneously they should be taught its usage to tackle the gap between market offering and usage as statistics depict that despite of digital advancements, the use of digital financial instruments is very low. This will ultimately aid in enhancing financial inclusion and will lead to sustainable and equitable growth of the economy (Yusufzai, 2015).

\subsection{Core Dimensions of Consumer Empowerment in Banking Sector 2.4.1. Financial Literacy and Education}

Financial literacy refers to the capability to understand financial products/services, financial matters and management of money/finances (Atkinson \& Messy, 2012). Financial education, information and guidance can empower consumers as it enables them to budget and manage their income, to save, invest and protect themselves against risks. Moreover, this education equips consumers with skills that lead to informed decisions and safeguards them against financial frauds and scams (Williams, 2011).

As financial products and services are getting more and more sophisticated, it is getting highly significant for individuals to manage their finances well, not only for their own financial well-being, but also for the smooth functioning of financial markets and the economy. (Kumar \& Qazi, 2016).

Globally various initiatives have been embarked in order to foster financial literacy and capability of the people through massive programs. The tools that are being used to enhance financial literacy include publications, booklets, website, online games, social media, workshops, training programs (for children as well as teachers), educational videos etc. They are specifically targeting youth and children in order to build their financial capability/knowledge at early age. Also, people in developed countries are more receptive and engaged in these initiatives as compared to developing countries (Cordray, 2014).

In Pakistan increased access and better choices of financial services are emerging. However, they are not 
transforming into effective use as they are being impeded by asymmetries of information and power difference between financial institutions and consumers. This imbalance is further growing as customers are less experienced and educated while the market offerings are getting more sophisticated. Research depicts that lack of financial literacy is the second most significant demand side restriction towards effective financial inclusion in Pakistan (Chakrabarty, 2012).

However, the dilemma in Pakistan is that the banks aren't conducting many independent initiatives to accelerate this concept. Few of the initiatives conducted by banks in Pakistan for financial literacy are as follows,

- National Bank of Pakistan has issued various publications to create awareness on financial matters (Khan, 2016).

- $\quad$ MCB conducted few awareness campaigns at to enhance financial literacy campaigns at various institutes. Also, for the well being of rural areas, various development programs were conducted under which farmers were approached and provided awareness on financial matters so that financial literacy increases (Pasha, 2016).

- Standard Chartered Bank (SCB) started a program named as 'Goal' which is an initiative to provide financial literacy, life skills and employability training to low-income girls (Yusufzai, 2015).

- Tameer Microfinance Bank created awareness about mobile banking, micro insurance and financial products/services through various campaigns that were conducted in rural areas like Mithi (Kumar \& Qazi, 2016).

- FINCA microfinance bank conducted financial awareness session named as "Samajh Bhooj Program" in a small village near Talagang (Kumar \& Qazi, 2016).

However, these initiatives are very minimal as compared to the need and global scenario. Therefore, The State Bank of Pakistan is putting various efforts for this purpose and is trying to encouraging banks to promote financial literacy on a massive scale. Some of the initiatives undertaken by State Bank of Pakistan for the cause are,

\subsubsection{National Financial Literacy Program}

National Financial Literacy Program (NFLP) is a program initiated by State Bank of Pakistan that aims at improving financial inclusion along with consumer awareness about their rights and obligations which will lead to a robust financial sector by providing basic financial literacy to the lower segment of Pakistan.

The distribution strategy involves street theatres, board games, comic strips, activity-based competitions, and website and media campaigns to reach out the masses on a larger scale. The Program comprises of seven basic themes which include consumer rights $\&$ responsibilities, debt management, branchless banking, banking products and services, investment, saving and budgeting (Anwar, 2012).

Furthermore, in future the initiative aims at,

- Nationwide launch: 1 million beneficiaries

- Introduction of children and youth components of the Financial Literacy Program

- Financial literacy will be made a part of school/college curriculum

Other than this program, SBP aims at initiating another long-term campaign to enhance financial literacy in the form of a special Financial Literacy Program (FLP) to cover both rural and urban areas (Anwar, 2012).

\subsubsection{Other Initiatives}

Ahmad (2016) has also highlighted the other initiatives taken by SBP like it conducts small awareness campaigns to educate consumers. The recent ones include,

- Bannu- Awareness programs on outreach of developmental financial services \& security features of bank notes

- Rawlakot- Awareness program on agriculture finance and growth of forestry sector

- Multan (Jhoke Wains)-Financial literacy session for small farmers

- Islamabad- Capacity Building program conducted by SBP Exchange Policy Department

Also, there are particular departments in SBP that are dedicating their time and efforts for consumer empowerment. In particular, Banking Conduct and Consumer Protection Department takes numerous initiatives to promote consumer awareness on financial matters like,

- Publications are issued frequently include pamphlets etc. on issues such as precaution in handling cheques, identity theft, skimming frauds, awareness messages for ATM users, pension collection etc.

- Lectures deliverance in universities, colleges and schools aimed at creating financial awareness.

\subsubsection{Digitalization}

Banks can use digitalization to create various innovative customer oriented products which can enrich customer experience. Adoption of digital solutions opens new avenues for banks and also enables them to make their services and processes more efficient which ultimately aids in creating better customer experiences. It can also create expediency for customers through reducing time, cost and efforts that are involved in conducting transactions. Also, the customers are empowered due to mobility of services as digitalization has led to greater accessibility. 
Globally, the banks as well as their customers have benefited a lot from adoption of innovative digitized solutions as the processes became more efficient, simpler and fast. Digitalization aids in standardization of processes which reduce chances of human error and therefore augments customer experiences (Bhutani \& Paliwal, 2015).

According to (Johnston, 2016) novel digital banking techniques are aimed at empowering consumers through more engaging customer experience and by delivering the customers what they want more efficiently. Canadian financial sector has adopted high level of digitalization which are tailored and designed to meet the changing needs of customers much more efficiently. According to (G, A, \& MA, 2016) customers are evaluating the services of their banks based on the convenience they provide through adoption of novel solutions. This has significantly affected customer satisfaction as they consider digitalization as an empowering tool as it creates more efficiency, transparency and safety.

In Pakistan, digitalization is also rapidly increasing as banks are adopting technological solutions in the light of its benefits and success globally. State Bank of Pakistan is also working upon digital banking solutions to empower consumers with greater access and convenience so that financial inclusion increases. According to (Shaikh, 2016) in order to achieve SBP's 2020 vision it is vital that customized digital solutions are provided to customers which are user friendly.

\subsection{Benefits of Consumer Empowerment 2.5.1. To Economy}

Consumer empowerment particularly through financial education and awareness aids in enhancing financial inclusion in the country by making the people realize its significance. Moreover, when consumers are provide effective redressal mechanisms, their trust in the formal channels increases which brings them towards financial channels. This financial inclusion foster sustainable development and financial stability in the economy as it leads to equitable growth of all sections of society and reduces inequality (Sharma \& Kukreja, 2013). Also, it provides numerous other benefits to the economy like World Bank's analysis of Mexico depicted that 10\% increase in financial inclusion lead to 7\% increase in employment, $5 \%$ increase in new businesses and 3\% increase and GDP (Montgomery, 2015). Thus, effectively empowering consumers leads to multiple positive effects on the economy.

\subsubsection{To Banks}

Customer empowerment is a significant factor for managing relationships with customers. It is about increasing customer value by providing additional access, content, education and commerce to wherever the customer is located.

Consumer empowerment also plays a key role in customer relationship management and has a positive impact on bank's performance as well. It also aids in augmenting customer satisfaction because when the customers are empowered through more information and better/user-friendly options like digitized solutions etc. they are able to take better decisions. This satisfaction creates better customer experiences, strengthens relationship with customers and contributes towards stronger brand equity and performance. (Bhat \& Darzi, 2016).

\subsubsection{To Consumers}

Empowering consumers through education (about financial products/services, digitalization, redressal methods etc.) enhances the awareness among consumers which enables them to make informed decisions in their best interest and fosters their financial stability. Also, empowerment initiatives like technological and digital advancements not only increase efficiency in banking system, but they also increase expediency for customers by making transactions much easier (Mijs, 2015).

\subsection{Financial Consumer Empowerment Trilogy}

According to the Organization for Economic Co-operation and Development (OECD) the trilogy or triad of Financial Inclusion, Financial Literacy and Consumer Protection has been recognized globally as intertwining threads in pursuit of Financial Stability. For any kind of stability, whether financial, economic, political or social, inclusive growth is an essential prerequisite. Inclusive growth, in turn, is largely driven by financial inclusion and an inclusive financial system (Chakrabarty, 2012). 


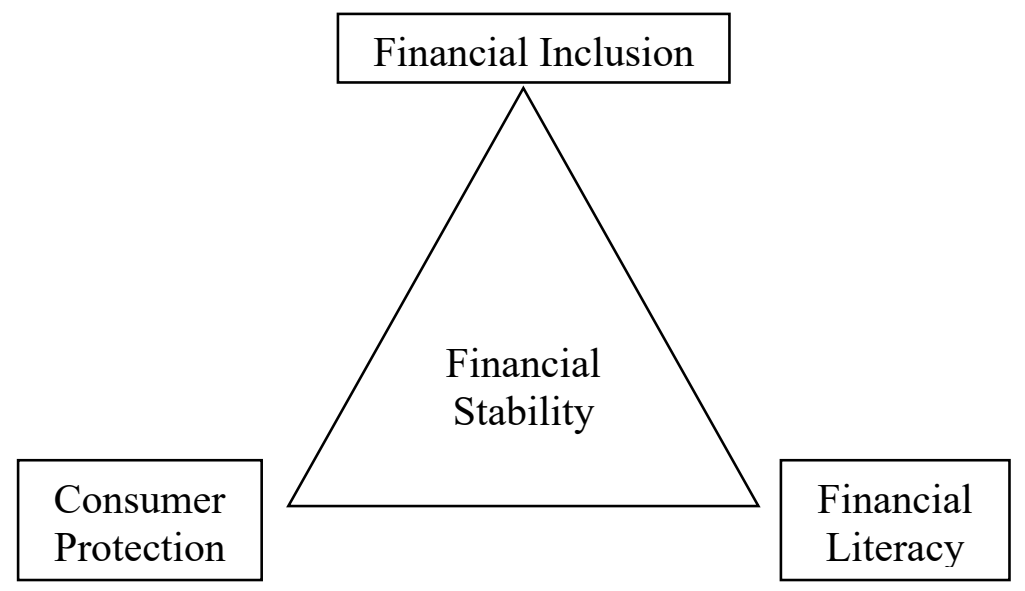

\subsection{Research Gap Analysis}

The research on consumer empowerment in banking sector aims to fill gap as substantial and detailed studies are not available in the local context on this emerging trend. Moreover, the research would also cater methodological gap as most of the researches conducted globally related to this topic are quantitative while this research will be qualitative in nature.

\section{RESEARCH METHODOLOGY}

\subsection{Research Design}

The research study is qualitative in nature that extracts the perceptions of managers in banking industry about the emerging trend of the consumer empowerment through exploratory strategy, which aims to lay groundwork for future studies/theories. This type of study is primarily used to explore or understand the underlying reasons for a particular phenomenon or to gain insights into a problem by gathering subjective data i.e. thoughts, opinions or beliefs (Wyse, 2011). The research has been conducted using mono-method i.e. qualitative approach as it provides an in-depth knowledge and understanding of importance, need, current scenario, benefits, impediments etc. of consumer empowerment in banking sector through managerial perspectives.

\subsection{Participants and Sample}

The research participants are managers of the registered banks that fall within the legal ambit of State Bank of Pakistan operating in Karachi. In addition, it includes those managers who have minimum one year of experience in the required domain. The data has been collected through in-depth interviews which has ceased at saturation level (Point at which no new information is expected to be generated).

\subsection{Sampling Technique}

The sampling method used for this research is non-probability judgmental / purposive sampling in which participants has been selected based on the purpose of the study with the expectation that each participant will contribute the required information and will add value to the study. Thus, the researcher decides what type of information is needed and according to his/her judgment finds people who are willing to share information by virtue of knowledge or experience (Etikan, Musa, \& Alkassim, 2016).

\subsection{Data Collection Procedure}

The research is based on both primary and secondary data. For primary data, the data collection method is interviews while the data collection tool is interview protocol. This protocol is basically a checklist that the interviewer follows and refers to during the interview to ensure that all relevant and required information is attained (Harrell \& Bradley, 2011).

The interview protocol consists of semi-structured and hybrid questions that have been adopted from research paper "Consumer Empowerment through Financial Literacy and Financial Capability Initiatives" (Clarke, 2015) and modified as per requirements. In addition the pilot testing, a preliminary trial or pre-test of research instrument i.e. interview protocol, has also been conducted through pilot interview to ensure that the proposed questions would extract the required and expected information (Castillo-Montoya, 2016). Moreover, pilot testing also aids in recognizing ambiguous statements in the interview protocol (Dikko, 2016). Furthermore, the secondary data has been collected from articles, journals etc. using internet database. 


\subsection{Reliability and Validity}

Reliability of research has been checked through member's checking in which respondents check the transcript formed after interview to ensure that there is no discrepancy and the information is similar to what they provided. Another way through which reliability has been checked is triangulation in which multiple researchers have checked the transcripts and interpret the results to eliminate any biasness. Moreover, the validity of the interview protocol has been checked through face validity which includes approval by research and domain expert.

\subsection{Concepts and Constructs}

\subsubsection{Consumer Empowerment}

Consumer empowerment refers to giving consumers power through resources such as greater information, understanding, options and resources that assist them in decision-making (Bauhaus, 2013).

\subsubsection{Financial Literacy}

Financial literacy comprises of the skill to manage and handle financial matters such as a bank account, budget, savings, investments, debt management etc. (Clarke, 2015).

\subsubsection{Financial Inclusion}

Financial inclusion ensures that affordable and appropriate financial products/services are accessible to all individuals including the lower income groups so that it can fulfill their needs. Moreover, it also includes provision of education to the customers so that they can use/avail the services by making optimal and informed choices (Aduda \& Kalunda, 2012).

\subsubsection{Financial Stability}

Financial stability is a situation in which the economy and financial system functions smoothly and all the economic agents can carry out financial transactions without facing uncertain and risky economic shocks (Aduda \& Kalunda, 2012).

\subsubsection{Digitalization}

Digitalization refers to the usage of technological, computerized and automated systems that can aid in making the processes more efficient. It is a form of social transformation that has emerged through embracement of digital technologies to create and share information (Bhutani \& Paliwal, 2015).

\subsubsection{Reputation}

Reputation refers to the status or image of a firm and is determined through public judgments that can progress or deteriorate over time. It includes the firm's respect, credibility etc. among public (Siano, Vollero, \& Palazzo, 2011). 3.6.7. Goodwill

Goodwill depicts the intangible value of a company through its brand name, customer relations, service quality etc. (Siano, Vollero, \& Palazzo, 2011).

\subsection{Ethical Considerations}

Ethical considerations are critical part of research. Ethics are standards and norms that differentiate between right and wrong. This research has been conducted under few important ethical considerations. Firstly, the participants were not subjected to any harm and were treated with dignity and respect. Secondly, the consent of the participants was obtained before conducting and recording interviews along with brief explanation of research. Thirdly, anonymity of participants has been ensured without any disruptive practices. Lastly, participants were given the right to withdraw at any point in time.

\subsection{Plan of Analysis}

All data gathered has been analyzed through subjective analysis (content analysis) which is used to extract the relevant information from the transcripts. This analysis technique is used to make valid and replicable inferences by interpreting and coding subjective data i.e. text and other non-numerical information through coding, sorting and sifting (Elo, 2014). 
CHAPTER 4: DISCUSSION AND ANALYSIS

4.1. Content Analysis Matrix

\begin{tabular}{|c|c|c|c|c|c|}
\hline & Categories & Participant 1 & Participant 2 & Participant 3 & Participant 4 \\
\hline 1 & $\begin{array}{l}\text { Construction of } \\
\text { "Consumer } \\
\text { Empowerment" } \\
\text { Meaning }\end{array}$ & $\begin{array}{l}\text { Conveying } \\
\text { information and } \\
\text { making resources } \\
\text { (financial, material } \\
\text { and informational) } \\
\text { and services } \\
\text { accessible }\end{array}$ & $\begin{array}{l}\text { To fulfill } \\
\text { consumer's need } \\
\text { and desires } \\
\text { Offering what they } \\
\text { need and want }\end{array}$ & $\begin{array}{l}\text { Listening to } \\
\text { customers and } \\
\text { bringing } \\
\text { innovative } \\
\text { solutions for their } \\
\text { problems. }\end{array}$ & $\begin{array}{l}\text { Guiding customers } \\
\text { step by step to } \\
\text { overcome their } \\
\text { problems }\end{array}$ \\
\hline 2 & $\begin{array}{l}\text { Need in } \\
\text { Banking Sector }\end{array}$ & $\begin{array}{l}11 \text { microfinance } \\
\text { banks are working } \\
\text { yet they have } \\
\text { taped only } 7 \% \text { of } \\
\text { the population in } \\
\text { the last } 17 \text { years }\end{array}$ & $\begin{array}{l}\text { Becoming need of } \\
\text { consumers. }\end{array}$ & $\begin{array}{l}\text { There is high lack } \\
\text { of knowledge even } \\
\text { in upper segment } \\
\text { of society. }\end{array}$ & $\begin{array}{l}\text { Consumers don't } \\
\text { have knowledge. } \\
\text { That's why they } \\
\text { don't utilize } \\
\text { banking services } \\
\text { properly. }\end{array}$ \\
\hline 3 & $\begin{array}{l}\text { Role of } \\
\text { Financial } \\
\text { Literacy } \\
\text { (education/ } \\
\text { awareness) }\end{array}$ & $\begin{array}{l}\text { Everyone should } \\
\text { have basic } \\
\text { knowledge of } \\
\text { financial products } \\
\text { specifically } \\
\text { Lending, Saving } \\
\text { and Insurance to } \\
\text { make better } \\
\text { financial decisions }\end{array}$ & $\begin{array}{l}\text { Individual can't } \\
\text { compromise on } \\
\text { wealth and health } \\
\text { hence knowledge } \\
\text { and protection will } \\
\text { be always } \\
\text { demanded from } \\
\text { consumer side. }\end{array}$ & $\begin{array}{l}\text { People are } \\
\text { confused about } \\
\text { various products in } \\
\text { market. Important } \\
\text { avenues for } \\
\text { financial } \\
\text { knowledge are } \\
\text { Account opening } \\
\text { and plastic money } \\
\text { (cards). }\end{array}$ & $\begin{array}{l}\text { With the help of } \\
\text { F.L consumers } \\
\text { will be able to save } \\
\text { their money and } \\
\text { time and also they } \\
\text { will be able to } \\
\text { understand } \\
\text { banking services } \\
\text { properly. }\end{array}$ \\
\hline 4 & $\begin{array}{l}\text { Role of } \\
\text { Digitalization }\end{array}$ & $\begin{array}{l}\text { Plays a vital role } \\
\text { User friendly and } \\
\text { convenient as well } \\
\text { as cost effective }\end{array}$ & $\begin{array}{l}\text { Helps in } \\
\text { standardization of } \\
\text { processes } \\
\text { Convenient and } \\
\text { cost effective } \\
\text { Broad vision needs } \\
\text { time to be } \\
\text { incorporated } \\
\text { Apps are } \\
\text { convenient and } \\
\text { easy to use }\end{array}$ & $\begin{array}{l}\text { Play a vital role, } \\
\text { convenient for } \\
\text { consumers } \\
\text { Enhancement of IT } \\
\text { Cost effective } \\
\text { Internet Banking }\end{array}$ & $\begin{array}{l}\text { Easy to access and } \\
\text { use, saves time and } \\
\text { money. } \\
\text { User friendly and } \\
\text { it also motivates } \\
\text { customer towards } \\
\text { learning of new } \\
\text { technology. }\end{array}$ \\
\hline 5 & $\begin{array}{l}\text { Level on } \\
\text { Significance of } \\
\text { Consumer } \\
\text { Empowerment }\end{array}$ & $\begin{array}{l}\text { Samajh Boojh } \\
\text { Program } \\
\text { Lectures } \\
\text { conducting in rural } \\
\text { areas, villages in } \\
\text { collaboration with } \\
\text { NGOs } \\
\text { SIM SIM } \\
\text { (emergency loan } \\
\text { or credit facility) } \\
\text { Media can be use - } \\
\text { fastest and high } \\
\text { reach }\end{array}$ & $\begin{array}{l}\text { Seminars } \\
\text { (awareness } \\
\text { programs) to clear } \\
\text { concepts in various } \\
\text { institutes } \\
\text { In } 2014 \text { Collective } \\
\text { Public Campaigns } \\
\text { Newspaper ads } \\
\text { Department and } \\
\text { personals dealing } \\
\text { with customers } \\
\text { entertaining their } \\
\text { queries }\end{array}$ & $\begin{array}{l}\text { There should be } \\
\text { workshops, } \\
\text { seminars, lectures } \\
\text { and advertising in } \\
\text { which familiar } \\
\text { terms should be } \\
\text { used that are easily } \\
\text { understandable by } \\
\text { customers } \\
\text { Orbit app - till } \\
\text { now } 20 \% \text { clientele } \\
\text { captured } \\
\text { Shifting people to } \\
\text { self } \\
\text { service/branchless } \\
\text { banking. }\end{array}$ & $\begin{array}{l}\text { My ABL app has } \\
\text { captured attention } \\
\text { of our customers } \\
\text { due to which } \\
\text { people prefer to do } \\
\text { branchless banking } \\
\text { because it's more } \\
\text { convenient. We } \\
\text { are doing many } \\
\text { seminars in } \\
\text { schools to } \\
\text { motivate students } \\
\text { to save and open } \\
\text { joint accounts with } \\
\text { their parents. }\end{array}$ \\
\hline
\end{tabular}




\begin{tabular}{|c|c|c|c|c|c|}
\hline & Categories & Participant 1 & Participant 2 & Participant 3 & Participant 4 \\
\hline 6 & $\begin{array}{l}\text { Challenges } \\
\text { Hindered in } \\
\text { Execution }\end{array}$ & $\begin{array}{l}\text { Lack of Trust and } \\
\text { Information } \\
\text { Fear in usage from } \\
\text { consumer side } \\
\text { Accessibility or } \\
\text { low reach } \\
\text { To understand the } \\
\text { level of consumer } \\
\text { knowledge }\end{array}$ & $\begin{array}{l}\text { Difficulty in } \\
\text { getting and } \\
\text { compilation of } \\
\text { data - Lack of } \\
\text { Centralized Data } \\
\text { which can help in } \\
\text { KYC } \\
\text { Fear of money loss } \\
\text { and lack of trust, } \\
\text { threat of taxes and } \\
\text { processes }\end{array}$ & $\begin{array}{l}\text { Lack of } \\
\text { willingness of } \\
\text { consumers to learn } \\
\text { new } \\
\text { things/processes. } \\
\text { Lack of bank's } \\
\text { responsiveness - } \\
\text { discrimination } \\
\text { from bank side. } \\
\text { Lack of ownership }\end{array}$ & $\begin{array}{l}\text { Lack of trust on } \\
\text { My ABL app. } \\
\text { Lack of interest } \\
\text { from consumer } \\
\text { side to learn new } \\
\text { things. Fear of } \\
\text { usage of new } \\
\text { banking mediums. }\end{array}$ \\
\hline 7 & $\begin{array}{l}\text { Effectiveness of } \\
\text { Consumer } \\
\text { Empowerment } \\
\text { Initiatives }\end{array}$ & $\begin{array}{l}\text { Mystery Shoppers } \\
\text { Returns of } \\
\text { Programs in terms } \\
\text { of customer base }\end{array}$ & $\begin{array}{l}\text { Data Analysis } \\
\text { Market Share as } \\
\text { through seminars } \\
\text { market share of } \\
\text { Islamic Banking } \\
\text { double (2000-2014 } \\
3 \% \text { then } 2014- \\
20177 \%)\end{array}$ & $\begin{array}{l}\text { Cold Calls } \\
\text { Statistic Analysis } \\
\text { Conversion Rate }\end{array}$ & $\begin{array}{l}\text { Consumer } \\
\text { feedback, market } \\
\text { share analysis, } \\
\text { conversion rate. } \\
\text { Downloads of app }\end{array}$ \\
\hline 8 & $\begin{array}{l}\text { Benefits for } \\
\text { Banks }\end{array}$ & $\begin{array}{l}\text { Publicity } \\
\text { Brand Equity and } \\
\text { Loyalty - Trust }\end{array}$ & $\begin{array}{l}\text { Word of Mouth } \\
\text { Recognition } \\
\text { Improvement in } \\
\text { performance and } \\
\text { services by } \\
\text { monitoring } \\
\text { feedbacks }\end{array}$ & $\begin{array}{l}\text { Recognition } \\
\text { Brand Name - } \\
\text { Differentiation } \\
\text { Increase in } \\
\text { Customer Base }\end{array}$ & $\begin{array}{l}\text { Gaining loyalty } \\
\text { and trust. } \\
\text { Gaining new } \\
\text { customers. } \\
\text { recognition }\end{array}$ \\
\hline 9 & $\begin{array}{l}\text { Benefits for } \\
\text { Consumers and } \\
\text { Economy }\end{array}$ & $\begin{array}{l}\text { Increase in } \\
\text { Consumer } \\
\text { Financial Literacy } \\
\text { will also raise } \\
\text { financial inclusion } \\
\text { and improve } \\
\text { standard of living }\end{array}$ & $\begin{array}{l}\text { Clears the concept } \\
\text { and understanding } \\
\text { of customers. } \\
\text { Helps them in } \\
\text { making better } \\
\text { decisions. } \\
\text { Enhances financial } \\
\text { inclusion }\end{array}$ & $\begin{array}{l}\text { Enhancement in } \\
\text { knowledge leads to } \\
\text { better decision } \\
\text { making and use of } \\
\text { finances. }\end{array}$ & $\begin{array}{l}\text { Better decision } \\
\text { making, } \\
\text { Saves time. } \\
\text { Provides } \\
\text { understanding of } \\
\text { financial services. }\end{array}$ \\
\hline 10 & $\begin{array}{l}\text { Responsibility } \\
\text { Body for } \\
\text { Consumer } \\
\text { Empowerment } \\
\text { Execution }\end{array}$ & $\begin{array}{l}\text { Banks should be } \\
\text { responsible and } \\
\text { accountable. } \\
\text { Efforts should be } \\
\text { taken collectively } \\
\text { by banks as well as } \\
\text { by regulator. }\end{array}$ & $\begin{array}{l}\text { Regulator's } \\
\text { responsibility is to } \\
\text { give guideline and } \\
\text { monitoring } \\
\text { practices. } \\
\text { It's bank's job to } \\
\text { implement those } \\
\text { guidelines. }\end{array}$ & $\begin{array}{l}\text { Regulator should } \\
\text { not only push } \\
\text { banks but also } \\
\text { work towards } \\
\text { consumer's side. It } \\
\text { should introduce } \\
\text { policies which are } \\
\text { acceptable by } \\
\text { consumers. } \\
\text { It's State bank } \\
\text { responsibility to } \\
\text { bring banks on one } \\
\text { platform. } \\
\text { We can educate } \\
\text { about our products } \\
\text { but not all } \\
\text { available in the } \\
\text { market. }\end{array}$ & $\begin{array}{l}\text { It is SBP's duty to } \\
\text { push banks for } \\
\text { implementation of } \\
\text { financial literacy } \\
\text { programs and } \\
\text { other policies } \\
\text { supporting the } \\
\text { stability of this } \\
\text { initiative. SBP } \\
\text { should also keep } \\
\text { check and balance } \\
\text { of all the problems } \\
\text { which are being } \\
\text { faced on the } \\
\text { consumer's side in } \\
\text { their future } \\
\text { policies. }\end{array}$ \\
\hline
\end{tabular}




\begin{tabular}{|c|c|c|c|c|c|}
\hline & Categories & Participant 1 & Participant 2 & Participant 3 & Participant 4 \\
\hline 11 & $\begin{array}{l}\text { Consumer } \\
\text { Empowerment } \\
\text { Future }\end{array}$ & $\begin{array}{l}\text { This concept will } \\
\text { widespread in } \\
\text { future it will } \\
\text { become } \\
\text { compulsory for } \\
\text { each and every } \\
\text { organization. }\end{array}$ & $\begin{array}{l}\text { Bright Future } \\
\text { Powerful } \\
\text { Consumers }\end{array}$ & $\begin{array}{l}\text { Everyone should } \\
\text { play their roles. } \\
\text { Untapped now but } \\
\text { in future it will } \\
\text { become common } \\
\text { and vital function } \\
\text { of bank. } \\
\text { Changes will occur } \\
\text { slowly and } \\
\text { gradually not } \\
\text { drastically. }\end{array}$ & $\begin{array}{l}\text { In future banks } \\
\text { will be giving } \\
\text { more importance } \\
\text { to it as it will } \\
\text { become one of the } \\
\text { main functions of } \\
\text { bank. }\end{array}$ \\
\hline
\end{tabular}

\begin{tabular}{|c|c|c|c|c|}
\hline & Categories & Participant 5 & Participant 6 & Participant 7 \\
\hline 1 & $\begin{array}{l}\text { Construction of } \\
\text { "Consumer } \\
\text { Empowerment" } \\
\text { Meaning }\end{array}$ & $\begin{array}{l}70 \text { percent are illiterate. } \\
\text { Consumers can be } \\
\text { empowered through } \\
\text { advancing them money at } \\
\text { reasonable rates along } \\
\text { with teaching them how } \\
\text { to use these services. } \\
\text { Everything including the } \\
\text { banking environment } \\
\text { should be made user } \\
\text { friendly. }\end{array}$ & $\begin{array}{l}\text { It is basically the sum of } \\
\text { all efforts that a bank } \\
\text { takes to educate a } \\
\text { customer so that customer } \\
\text { will be aware of the } \\
\text { banking services. }\end{array}$ & $\begin{array}{l}\text { It is an essential } \\
\text { proposition in order to } \\
\text { retain your customers }\end{array}$ \\
\hline 2 & $\begin{array}{l}\text { Need in } \\
\text { Banking Sector }\end{array}$ & $\begin{array}{l}\text { Consumer doesn't } \\
\text { understand microfinance } \\
\text { bank's functions and } \\
\text { products. }\end{array}$ & $\begin{array}{l}\text { It is a need more in } \\
\text { banking sector than in any } \\
\text { sector like choosing a car } \\
\text { or house that undergoes } \\
\text { long term impact. }\end{array}$ & $\begin{array}{l}\text { Consumer's likes and } \\
\text { dislikes are more } \\
\text { preferable in formulating } \\
\text { policies. }\end{array}$ \\
\hline 3 & $\begin{array}{l}\text { Role of } \\
\text { Financial } \\
\text { Literacy } \\
\text { (education/ } \\
\text { awareness) }\end{array}$ & $\begin{array}{l}\text { It is very important as it } \\
\text { will help consumers in } \\
\text { understanding our } \\
\text { products. }\end{array}$ & $\begin{array}{l}\text { People aren't aware of the } \\
\text { basic bank services as } \\
\text { population is raising day } \\
\text { by day but banks are not } \\
\text { showing any } \\
\text { improvement to bring } \\
\text { more customers }\end{array}$ & $\begin{array}{l}\text { People are still not } \\
\text { approached to banks. } \\
\text { Many are not aware of } \\
\text { basic financial } \\
\text { products/services and } \\
\text { their usage hence } \\
\text { educating them is vital } \\
\text { and most important part of } \\
\text { consumer empowerment }\end{array}$ \\
\hline 4 & $\begin{array}{l}\text { Role of } \\
\text { Digitalization }\end{array}$ & $\begin{array}{l}\text { Easy paisa is the name of } \\
\text { branchless banking. You } \\
\text { can buy movie, bus } \\
\text { tickets. We are replacing } \\
\text { plastic money with mobile } \\
\text { money. Mobile wallet will } \\
\text { soon be introduced. Credit } \\
\text { rating score will also be } \\
\text { introduced. }\end{array}$ & $\begin{array}{l}\text { It plays a main role in } \\
\text { paperless transaction at } \\
\text { any given time and now it } \\
\text { does not depends on any } \\
\text { human as mobile app is } \\
\text { ready to help us }\end{array}$ & $\begin{array}{l}\text { Changing the system of } \\
\text { banks as compare to } \\
\text { banks of 90s era. Making } \\
\text { things more convenient } \\
\text { and user friendly. }\end{array}$ \\
\hline
\end{tabular}




\begin{tabular}{|c|c|c|c|c|}
\hline 5 & $\begin{array}{l}\text { Level on } \\
\text { Significance of } \\
\text { Consumer } \\
\text { Empowerment }\end{array}$ & $\begin{array}{l}\text { Our employees visit } \\
\text { different places especially } \\
\text { in rural areas and we } \\
\text { organize seminars to } \\
\text { increase awareness. This } \\
\text { also aids us in promoting } \\
\text { our own bank. We also } \\
\text { distribute our pamphlets } \\
\text { which are written in } \\
\text { regional languages so that } \\
\text { people can easily } \\
\text { understand them. }\end{array}$ & $\begin{array}{l}\text { Card Products like debit } \\
\text { and credit cards, discount } \\
\text { allowances have been } \\
\text { signed so that people } \\
\text { come from more these } \\
\text { channels as compare to } \\
\text { conventional channels. } \\
\text { Plus, Mobile banking also } \\
\text { have been started } \\
\text { Promotion \& Social } \\
\text { Media Base }\end{array}$ & $\begin{array}{l}\text { Offering multiple } \\
\text { languages in systems like } \\
\text { ATM. } \\
\text { Hiring people who know } \\
\text { language of locality in } \\
\text { which branch is located. } \\
\text { Installing pictorial } \\
\text { guidelines. } \\
\text { Biometric ATMs. } \\
\text { Simplistic branding to } \\
\text { reduce fears. } \\
\text { Worked on Branding and } \\
\text { Wed designing to make t } \\
\text { more users friendly and } \\
\text { consistent. }\end{array}$ \\
\hline 6 & $\begin{array}{l}\text { Challenges } \\
\text { Hindered in } \\
\text { Execution }\end{array}$ & $\begin{array}{l}\text { Credit expansion in our } \\
\text { country is less. Micro } \\
\text { finance fund is not } \\
\text { established by State Bank } \\
\text { of Pakistan. Commercial } \\
\text { banks are rather making } \\
\text { investments than giving } \\
\text { loans which is hindering } \\
\text { empowerment of } \\
\text { consumers }\end{array}$ & $\begin{array}{l}\text { Still many people are not } \\
\text { aware of banking } \\
\text { services. } \\
\text { People doesn't know } \\
\text { much about digital } \\
\text { banking so there is a lack } \\
\text { of digital knowledge } \\
\text { among people }\end{array}$ & $\begin{array}{l}\text { Language barrier } \\
\text { Willingness and } \\
\text { acceptance from } \\
\text { consumer side } \\
\text { Fear }\end{array}$ \\
\hline 7 & $\begin{array}{l}\text { Effectiveness of } \\
\text { Consumer } \\
\text { Empowerment } \\
\text { Initiatives }\end{array}$ & $\begin{array}{l}\text { Statistical analysis of } \\
\text { usage of digitalized } \\
\text { services } \\
\text { Consumer awareness tests }\end{array}$ & $\begin{array}{l}\text { Consumer Awareness } \\
\text { Level of deposits } \\
\text { Calls to customers }\end{array}$ & $\begin{array}{l}\text { Deposits } \\
\text { Consumer's level of } \\
\text { Usage } \\
\text { Conversion Rate }\end{array}$ \\
\hline 8 & $\begin{array}{l}\text { Benefits for } \\
\text { Banks }\end{array}$ & $\begin{array}{l}\text { Will increase our } \\
\text { promotion } \\
\text { Better Reputation } \\
\text { Increase in market share }\end{array}$ & $\begin{array}{l}\text { Deposits increase } \\
\text { Increase in customers } \\
\text { base }\end{array}$ & $\begin{array}{l}\text { More customers } \\
\text { More deposits }\end{array}$ \\
\hline 9 & $\begin{array}{l}\text { Benefits for } \\
\text { Consumers and } \\
\text { Economy }\end{array}$ & $\begin{array}{l}\text { Our mark up rate is as low } \\
\text { as } 14 \text { percent. Consumers } \\
\text { are being empowered } \\
\text { through this credit so that } \\
\text { they can make their own } \\
\text { lives better which } \\
\text { subsequently leads to } \\
\text { betterment of economy as } \\
\text { people start to prosper }\end{array}$ & $\begin{array}{l}\text { Tax measured money } \\
\text { All transactions will be } \\
\text { recorded } \\
\text { Security purpose }\end{array}$ & $\begin{array}{l}\text { Consumers can start } \\
\text { banking from their smart } \\
\text { phone by sitting at home. } \\
\text { Safety of money }\end{array}$ \\
\hline 10 & $\begin{array}{l}\text { Responsibility } \\
\text { Body for } \\
\text { Consumer } \\
\text { Empowerment } \\
\text { Execution }\end{array}$ & $\begin{array}{l}\text { Both, banks as well as } \\
\text { SBP. Like, SBP has } \\
\text { introduced National } \\
\text { Financial Literacy } \\
\text { Program and we are also } \\
\text { helping them in this } \\
\text { initiatve as it is quite } \\
\text { lucrative. }\end{array}$ & $\begin{array}{l}\text { Banks should teach their } \\
\text { customer in helpline in } \\
\text { multiple languages and } \\
\text { print the brochures, } \\
\text { pamphlets in multiple } \\
\text { languages so that } \\
\text { everyone can understand. }\end{array}$ & $\begin{array}{l}\text { Banks should make the } \\
\text { policies according to the } \\
\text { likes and dislikes of } \\
\text { consumer and general } \\
\text { requirements in the } \\
\text { society }\end{array}$ \\
\hline 11 & $\begin{array}{l}\text { Consumer } \\
\text { Empowerment } \\
\text { Future }\end{array}$ & $\begin{array}{l}\text { It has a bright future and } \\
\text { consumer will become } \\
\text { financial literate. }\end{array}$ & $\begin{array}{l}\text { Total digitalization } \\
\text { Digital branch concept } \\
\text { Tangible laws regarding } \\
\text { customer protection/ }\end{array}$ & $\begin{array}{l}\text { This concept will expand } \\
\text { day by day just like } \\
\text { bank's transformation } \\
\text { from last century to } \\
\text { current }\end{array}$ \\
\hline
\end{tabular}




\subsection{Discussion}

Many of the respondents consider educating consumers about the availability of financial product and services as a vital portion of consumer empowerment as it aids them in making optimal decisions which is coherent with the findings of the literature that suggests the same. However, various other dimensions and aspects of consumer empowerment have been discovered such as fulfilling the evolving needs of consumers by offering them the right products/services, bringing innovative solutions to cater the problems faced by consumers along with inculcating a user friendly environment in banks so that customers can trust and visit banks without any hesitation. Moreover, few of the representatives of microfinance banks also consider advancing loans to consumers at affordable rates as a form of empowerment as it provides them the opportunity to get financially independent like by utilizing those loans to establish their businesses or by acquiring education etc.

According to the respondents, the most vital dimensions of consumer empowerment include initiation of innovative solutions by leveraging technology along with simultaneously educating the consumers about the usage of these products and services as it would empower them to take well informed decisions in their best interests. Moreover, transparency should be strictly preserved i.e. the consumers must be disclosed all the relevant information and they should be safeguarded from all sorts of discriminatory practices and deceptions.

Concordant with the literature, all the respondents consider that consumer empowerment especially in the form of educating consumers about financial products/services is highly needed in the banking sector of Pakistan because despite of increasingly convenient, user friendly and efficient banking solutions, effective usage is being hindered due to lack of knowledge on the side of consumers. This is also one of the reasons because of which banks are still unable to tap majority of the population. Hence, the first step in order to empower consumers is to educate them and provide them awareness so that they can overcome the fear and reluctance of using formal banking channels. Then, consumers can be further empowered to a higher extent by fulfilling and catering their needs effectively.

All the respondents consider financial literacy or education as extremely vital and this is the area where Pakistan lacks the most. Few of the respondents highlighted the fact that banks have recently started working aggressively on financially educating the consumers due to pressure and guidance from the regulator i.e. State Bank of Pakistan. The banks have been directed to provide complete details of services to the consumers so that they don't fall a prey to deception and SBP has also issued a financial literacy book which must be present at every outlet of banks. Moreover, in order to foster the implementation, SBP also conducts audits through mystery shopping to ensure that banks are following the guidelines.

Various initiatives have been suggested by respondents that can aid in increasing financial education such as conducting seminars in schools/colleges/universities, training sessions, inculcating financial education in the curriculum, publications in regional languages as well as adoption of digital avenues like websites, social media etc and advertising (promoting the category) to spread knowledge and awareness among children and educated people as lack of financial knowledge even persists among upper stratum of the society. Moreover, in order to tap rural population, sessions should be conducted in their regional languages. Some of these initiatives are already being conducted but not frequently and on wide scale. However, one of the respondents highlighted that from the consumer's side lack of willingness to learn financial services is hindering the motives of these initiatives.

The most vital avenues of financial literacy as enlightened by the respondents include, lending, saving, insurance, plastic money and account opening. Many of them are quite basic but possess variety of options and packages which are not known or often misunderstood by the consumers. Moreover, the knowledge should not only be provided in terms of availability of products/services but their usage should also be taught/ conveyed so that consumers can switch their habits. For instance, couple of the respondents highlighted the fact that despite of online bill payment facility consumers still visit banks to do the same. Many of them are also aware of this online facility yet they don't know the appropriate way to conduct the transaction and hence they continue using the old methods as in our society people are less receptive and eager to learn by themselves.

The respondents consider that digitalization has broadened the horizons of banks in terms of efficiency and facilitating consumers. Majority of them highlighted the fact that incorporating technological solutions makes things easier, convenient as well as cost effective which was also supported by the literature. Nevertheless, some of the bank representatives perceive it from a broader perspective because they consider it as a major transformation that will further grow rapidly in future and will substitute current methods of operating and modes of conducting financial transactions. Also, one of the respondents highlighted that digitalized processes also aid in making things standardized which in turn aids in reducing chances of errors hence saving costs along with customer satisfaction.

Moreover, few of the respondents highlighted that digitalization has led to less reliance on people rather applications are always there to guide and help consumers. Also, one of the respondent mentioned that digitalization in Pakistan is more concentrated towards empowering the upper segment of society as despite of access; very few people have the knowledge to utilize these services. Globally, along with adoption of digital techniques consumers are being taught simultaneously about its usage to avoid the gap whereas in Pakistan the 
gap is further increasing due to lack of initiatives and willingness from consumers to learn and adapt.

In banking sector, the current scenario or level in terms of consumer empowerment initiatives is constantly improving as banks are accelerating their efforts in this avenue. The representatives of the banks highlighted various initiatives that they are conducting. For instance, some banks mentioned that they conduct different awareness campaigns by collaborating with NGO's every now and then. Similarly, some of the banks conduct seminars in villages as well as in urban educational institutes. Moreover, various banks mentioned that they are also empowering their consumers through digital applications and mobile banking which is making things more convenient and user friendly. The consumers are also being provided lucrative offers through collaborations on the usage of these applications like in the form of discounts and deals so that they can be motivated to try these applications. Moreover, some respondents highlighted that they also spread information through newspaper ads and their customer handling departments ensure that the customers are treated fairly and their queries are entertained.

Likewise, some of the respondents enlightened that they are offering multiple languages in systems like ATM, using biometric ATM, hiring people who know local languages, installing pictorial guidelines, making website more and more user friendly etc. in order to motivate and facilitate the consumers.

Thus, initiatives are being taken which have been accelerated in the recent year however, there is still long way to go and vast room for improvement as most of the banks are trying to play their minimal part to facilitate consumers but a collaborative effort is absent to promote empowerment among consumers in the sector as a whole. Also, there is lack of a focused strategy in designing these initiatives just like globally different initiatives are planned for children, youngsters, adult etc. but in Pakistan this is not the case.

The respondents highlighted the challenges that are hindering the execution of consumer empowerment initiatives. On the consumer's side, they don't trust the banks i.e. there is threat of theft, taxes, complicated processes etc. and therefore they fear using banking services. The level of engagement is very less among consumers in Pakistan as they are less receptive and unwilling to learn themselves. Moreover, few of the respondents also consider language barrier as a major obstacle. Also, financial innovation makes products and services more complex for consumers to understand

From the bank's side, reaching consumers/finding appropriate target audience, understanding their knowledge/mindset and gathering them on a platform is a major challenge along with tracking the effectiveness of these initiatives. One of the respondent mentioned that difficulty in getting and compilation of data also creates barrier in effective execution. One respondent highlighted that discriminatory practice from bank' side is hindering consumer empowerment as they are often treated unfairly. Likewise, a microfinance bank mentioned that the commercial banks are working in their interest and therefore investing in government securities rather than expanding credit which is also a barrier in empowering consumers because this money should be granted to them so that they can make their lives better.

Respondents shared several ways to measure and gauge the effectiveness of these initiatives. Firstly, banks usually check return or outcome of initiatives through statistical analysis i.e. through calculating the conversion rate, increase in market share, increase in customer base, frequency of usage of digital apps etc. Secondly, the effectiveness is also checked by making cold calls to customers to gauge their awareness level i.e. through consumer awareness tests. Moreover, another technique is mystery shopping which is done by upper management in the branches to ensure that at operational level the requirements are being met. Also, the technique of mystery shopping is adopted by the regulator to ensure that whether the banks are dealing properly with customers or not, whether they are disclosing the basic required information or not, whether they are entertaining customer's queries properly or not etc.

All respondents emphasized that consumer empowerment initiatives and programs are not only cost for banks instead they are rather investments as they lead to lucrative outcomes. This is because when the banks are taking these initiatives, they are also promoting themselves as people specifically unbanked ones recognize these banks and give them priority over others when they decide to avail financial services through formal banking channels. This leads to an increase in customer base as well as market share because when people have knowledge, they start utilizing these services. Moreover, it also enhances the reputation of the bank and creates its publicity and promotion.

These initiatives also enhance customer satisfaction because when they are provided convenience, proper information, options and are facilitated it increases their loyalty and they also start to spread positive word of mouth. Moreover, it also becomes a competitive edge or point of differentiation for banks. Few respondents also mentioned that customer's feedback also helps banks in improving products and services. Thus, all of these initiatives for the betterment of consumers ultimately aid banks in increasing their brand equity, profits and growth.

Many respondents acknowledged the fact that consumer empowerment initiatives aid in making the lives of consumers better in terms of better and informed financial decisions and convenient usage. According to microfinance banks, educating consumers will improve standard of living of many individuals along with raising financial inclusion in the economy. Moreover, in long run greater access to financial services and better financial 
decisions can help in reducing poverty. Moreover, Islamic banks quoted collective efforts on giving awareness about Islamic vs. conventional banks clear the concept of consumers regarding Islamic banking which also helps in increasing the market share and reputation of Islamic banks.

Most of the respondents considered that banks should be responsible and accountable for these initiatives as this would not only benefit the consumers but them as well. However, efforts would be much effective if taken collectively by the banks as well as by regulator. Many respondents also highlighted that the regulator is actively struggling on enhancing consumer empowerment initiatives such as through National Financial Literacy Program and through dedicated efforts of a particular department by the name of 'Banking Conduct and Consumer Protection Department'. Moreover, few respondents also said that it's the responsibility of regulator to bring all banks on one platform, give guidelines and monitor practices as banks themselves can only educate customers about their own product and services rather than general financial knowledge or about all the financial products and services offered in market. Also, banks themselves can succeed in targeting the existing customer base but it is rather difficult to target potential customers hence collaboration is needed (Devi \& Mehar, 2020).

In addition, one respondent also mentioned that regulator should not only push banks, instead it should also consider consumer's side as their involvement is highly critical to make these efforts worthwhile. Therefore, they should introduce such policies which are acceptable by consumers. Furthermore, the respondent also mentioned that the efforts will bring gradual change. However, if regulator puts high pressure to inculcate drastic changes then it can be detrimental as it can hurt the operations and industry.

According to all respondents this concept has a bright future and scope. Respondents mentioned that after few years consumer empowerment will be considered as one of the most vital function of banks. Also, markets which are untapped now will become banked through financial education and digitalization will take over conventional banking system slowly and gradually. One respondent mentioned that this concept will expand day by day just like bank's transformation from last century to current.

Some respondents talked about different avenues of consumer empowerment. According to one respondent, one of the indirect reasons behind emergence of this concept is wording on sustainable development goals (SDGs) i.e. our regulator is working on consumer empowerment to achieve the SDGs. One respondent quoted the example of government disbursement to consumers through respective banks and mentioned that it is a difficult task to know the customers, their practices and transforming them to new practices. Few respondents mentioned that customers are not aware of their rights and hence they do not ask for details and then there are certain jay customers who misuse their rights against banks (Devi \& Devi, 2014). One respondent also mentioned that usually in Pakistan's banking sector, bankers do discriminate customers on the basis of their financial position and account balance which also creates resistance for customers hence things will be better if everyone knows his/her role and unfair treatment is gets strictly prohibited. In addition, one respondent emphasized that there is also difference of opinion within banks and at this point in time most of the banks, many other things are given preference over working on consumer empowerment however in future it will become a priority to retain consumers especially when competition will increase and consumers will get more aware of their rights.

\section{CONCLUSION}

\subsection{Conclusion}

Thus, this study explores the managerial perspectives of banking industry of Pakistan about the emerging trend of consumer empowerment through qualitative approach. The research has been conducted with the help of in-depth interviews of managers to gain deep insights of their perception, views and opinions. The major results gathered from these interviews are summarized below.

Firstly, all respondents consider empowering consumers as one of the emerging and vital function of banks. However, the perception about meaning of consumer empowerment and its vital areas varies greatly. For few, educating the consumers about financial products and services is most important while for others providing convenience through digitalization, inculcating user friendly environment, being honest with the consumers, giving them choices etc. are most imperative. Secondly, all the respondents agree that the need to strengthen consumer empowerment especially in the form of creating awareness among consumers about digitalized and other financial products/services is highly essential due to major lacking of financial knowledge in the country. This also one of the key reasons because of which financial inclusion in the country is very low. Thus, educating consumers about appropriate usage of financial products/services, its pros and cons etc. will aid in tapping the unbanked population by alleviating the lack of understanding and fears from consumer side which are hindering them from moving towards formal banking channels (Devi \& Devi, 2014).

Thirdly, all respondents consider financial literacy as an initial and foremost step towards consumer empowerment because until consumers don't possess understanding, all the other initiatives of empowering them won't be very effective. Some of the respondents also highlighted that the regulator is actively working on this avenue and directing banks to so as well. The respondents also consider empowering through digital mediums as one of the vital dimension of consumer empowerment. This is because these innovative solutions and user friendly 
means of transaction are more convenient and easy to use for consumers as well as aids to reduce hesitation from consumer side. Fourthly, participants highlighted the status of consumer empowerment in their respective banks such as microfinance banks have conducted various session, awareness campaigns to educate their consumers, similarly sessions have been conducted by Islamic banks to clear concepts of consumers about Islamic financial products. Likewise, many applications have been offered by various banks to facilitate ease of transactions. Also, few banks mentioned that they have also introduced biometric ATMs and ATMs in multiple languages for the convenience of consumers.

Moreover, impediments in execution of consumer empowerment initiatives have also been highlighted by participants. Challenges from consumer's side include lack of trust, fear from banking services and complicated processes, language barriers and lack of consumer's willingness to learn. However, challenges from supply side are difficulties in tracking in right audience, bringing the target audience on one platform, problems in compilation of data and follow up results, unhelpful attitude and behavior of some of the employees of banks towards consumers etc. Furthermore, respondents also mentioned several ways to gauge the outcome of these initiatives like through conversion rate, statistical analysis, mystery shopping, increase in customer base and deposits etc.

In addition, respondents also admitted that working on consumer empowerment is not only beneficial for consumers to make better financial decisions and economy in terms of standard of living, financial inclusion etc. but it is also favorable for banks. This is because, these initiatives raise customer satisfaction, provide recognition, lead to bank's promotions and publicity, generate positive word of mouth WOM and become a source of competitive edge. This ultimately results in increase in customer base of respective banks.

Additionally, it has also been admitted by the representatives that banks should invest a lot more in consumer empowerment initiatives and should play its role. However, few also highlighted that it is the responsibility of the regulator to bring banks on a single platform to direct collective efforts which will be much effective as compared to separate efforts. Lastly, all the respondents considered bright future of consumer empowerment and also highlighted that this concept will be given much more importance in future specially as competition increases and consumer gets more aware of his/her rights. Many respondents in fact considered that it will be a top of priority for banks because consumers will demand it and in order to be sustainable, fulfillment of consumer's demand is necessary (Devi \& Devi, 2014).

Thus, from the findings obtained through this research, it can be concluded that consumer empowerment is becoming a vital part of banking industry and although the initiatives are being conducted to a minimal extent however they have accelerated swiftly as compared to previous year. This is because the regulator has actively started directing and guiding banks to widespread consumer empowerment in its essence i.e. through financially educating and facilitating consumers from every aspect. Hence, all the research objectives have been achieved well through exploratory strategy. The results of this study can be used by regulator to understand the views of banking sector towards consumer empowerment. Moreover, it can also be used by banks and other financial institutions to understand a cumulative perspective and current situation of consumer empowerment which can aid them in understanding which areas they should tap and how i.e. planning as well as execution.

\subsection{Recommendations}

- The banks should invest more efforts in spreading financial awareness among consumers for which more focused strategies should be made based on demographic factors like age, gender etc. For instance, different tools like games and activities can be used for educating children. Similarly, online portals can be used for targeting youngsters etc.

- In order to increase awareness and financial capability, financial education should be inculcated in the curriculum of schools so that children can get exposure of this avenue from a very early age.

- $\quad$ The banking environment should be made more user-friendly through alleviating issues like language barriers.

- The regulatory authority should make it mandatory for banks to conduct certain level of initiatives for educating the consumers about different financial products and services including the digital mediums so that it can turn into effective usage

- The regulator should create awareness among consumers about their rights on massive scale to ensure they are not deceived or discriminated. Also, awareness should be given about complaint mechanism as many consumers are still unaware about banking ombudsman.

- $\quad$ From regulatory side, not only banks should be pushed but initiatives should also be directed towards increasing the level of consumer engagement so that consumers themselves show willingness to learn.

- The regulatory body should bring banks on a single platform so that a collaborative effort can be made for more comprehensive and effective programs.

- $\quad$ The banks should place high emphasis on raising awareness among consumers and treating them right because along with empowering the consumers, it will also aid them in increasing their customer base 
along with publicity.

- The key areas where financial knowledge gap persists should be given high priority like borrowing, insurance, digital applications etc.

- Consumer empowerment initiatives undertaken by banks should be monitored by regulators on timely basis through audits, mystery shopping etc.

\subsection{Area of Future Research}

In future, as the concept further refines and becomes widespread, research can be done upon the impact that consumer empowerment has created which can be from banking as well as consumer aspect. Moreover, future researches can be done solely from demand side i.e. consumers to gauge their level of awareness, their stance and requirements on empowerment etc.

\section{REFERENCES}

Aduda, J., \& Kalunda, E. (2012). Financial Inclusion and Financial Sector Stability With Reference To Kenya: A Review of Literature. Journal of Applied Finance \& Banking .

Ahmad, S. (2016). Responsible banking conduct is an imperative for sustainable growth: Deputy Governor, State Bank of Pakistan. Asianet Pakistan .

Ahmed, D. S. (2015). Advancing Financial Inclusion through Financial Education in Pakistan. State Bank of Pakistan .

Anwar, Y. (2012). Financial Literacy Program to serve the interests of all financial sector stakeholders. State Bank of Pakistan.

Ardic, O. P., Ibrahim, J., \& Mylenko, N. (2011). Consumer Protection Laws And Regulations In Deposit And Loan Services: A Cross-Country Analysis With A New Data Set.

Atkinson, A., \& Messy, F.-A. (2012). Measuring Financial Literacy. OECD Working Papers on Finance, Insurance and Private Pensions .

Atkinson, A., \& Messy, F.-A. (2013). Promoting Financial Inclusion through Financial Education. OECD Working Papers on Finance, Insurance and Private Pensions .

Bauhaus, J. M. (2013). What Does Empowerment Mean in Marketing? azcentral .

Bhat, S. A., \& Darzi, M. A. (2016). Customer relationship management: An approach to competitive advantage in the banking sector by exploring the mediational role of loyalty. International Journal of Bank Marketing .

Bhutani, S., \& Paliwal, Y. (2015). Digitalization: A Step towards Sustainable Development. OIDA International Journal of Sustainable Development .

Broniarczyk, S., \& J.G.Griffin. (2014). Decision difficulty in the age of consumer empowerment . Journal of Consumer Psychology.

Castillo-Montoya, M. (2016). Preparing for Interview Research: The Interview Protocol Refinement Framework. The Qualitative Report .

Chakrabarty, K. C. ( 2012). Financial literacy and consumer protection . BIS central bankers'speeches .

Clarke, L. (2015). Consumer Empowerment through Financial Literacy and Financial Capability Initiatives . Financial Services Board.

Cordray, R. (2014). Financial Literacy Annual Report. Consumer Financial Protection Bureau .

Devi, A., \& Mehar, A., (2020). Effects of audit committee on audit expectation gap- mediating role audit quality. Journal of mechanics of continua and mathematical sciences, (6), 162-181

Devi, A., \& Devi, S. (2014). Audit expectation gap between auditors and users of financial statements. European Journal of Business and Management, 6(14), 75- 82.

Devi, A., \& Devi, S. (2014). Determinants of firms' profitability in Pakistan. Research Journal of Finance and Accounting, 5(19), 87-91.

Devi, S., \& Devi, A. (2014). Determinants of School Enrolment in Pakistan. Journal of Education and Practice www. iiste. org ISSN, 2222-1735.

Dikko, M. (2016). Establishing Construct Validity and Reliability: Pilot Testing of a Qualitative Interview for Research. The Qualitative Report .

Elo, S. (2014). Qualitative Content Analysis: A Focus on Trustworthiness. SAGE Open .

Etikan, I., Musa, S. A., \& Alkassim, R. S. (2016). Comparison of Convenience Sampling and Purposive Sampling. American Journal of Theoretical and Applied Statistics .

G, W., A, T., \& MA, T. (2016). The Impact of Electronic Banking on Customers' Satisfaction in Ethiopian Banking Industry. Journal of Business \& Financial Affairs .

Harrell, M. C., \& Bradley, M. A. (2011). Data Collection Methods. National Defense Research Institute .

Hunter, G. L., \& Garnefeld, I. (2011). When does Consumer Empowerment Lead to Satisfied Customers? Some Mediating and Moderating Effects of the Empowerment-Satisfaction Link . Journal of Research for Consumer . 
Johnston, C. (2016). Innovations In Digital Banking Designed To Empower Customers. Industry and Business .

Khan, O. A. (2016). Corporate Social Responsibility (CSR). National Bank of Pakistan Publications .

Koning, A., \& Valenzuela, M. (2015). Empower the Customer to Choose and Use Financial Services. CGAP .

Kumar, A. R., \& Qazi, M. (2016). The Essential Microfinance. Notion Press.

McShane, L., \& Sabadoz, C. (2015). Rethinking the concept of consumer empowerment: recognizing consumers as citizens. International Journal of Consumer Studies .

Mijs, W. (2015). Importance of Financial Education . European Banking Federation .

Montgomery, D. (2015). The Role of Financial Inclusionon Economic Growth: Challenges and Perspectives. Alliance for Financial Inclusion (afi) .

Pasha, M. (2016). What Will It Take for Pakistan to Achieve Financial Inclusion? The World Bank .

Rosenbaum, S. (2015). The New World Of The 'Empowered Consumer'. Forbes .

Shaikh, A. (2016). Banking on digital inclusion. Aurora .

Sharma, D. A., \& Kukreja, M. S. (2013). An Analytical Study:Relevance of Financial Inclusion For Developing Nations. International Journal Of Engineering And Science .

Siano, A., Vollero, A., \& Palazzo, M. (2011). Exploring the role of online consumer empowerment in reputation building. Journal of Brand Management .

Week, E. M. (2015). Financial Education - National Strategies In Europe. European Money Week .

Williams, T. (2011). Empowerment of Whom and for What? Financial Literacy Education and the New Regulation of Consumer Financial Services.

Wyse. (2011). What is the Difference between Qualitative Research and Quantitative Research. Retrieved from Snap Survey.

Yusufzai, A. (2015). 100 Million Pakistani Adults are Still Without Access to Financial Services. ProPakistani .

\section{APPENDIX}

\section{Interview Protocol}

1) Do you think the concept of consumer empowerment exists?

2) How would you define consumer empowerment?

- Different components/dimensions of consumer empowerment

- Most important ones (reasons/why)

- $\quad$ Need in banking sector of Pakistan (reasons)

3) Do you think financial education/awareness can play a vital role in empowering consumers in banking sector? Why?

- Specific/vital areas (in banks) about which the consumers should possess knowledge

- Suggestions of initiatives for enhancing financial education in Pakistan

4) How is digitalization helping in empowering customers of different segments in banking sector? (Benefits)

- Challenges that are hindering effective usage of digital solutions among consumers

- $\quad$ Suggestions for tackling this reluctance (i.e. how)

5) Status of consumer empowerment in your bank i.e. (Have you taken any initiatives or planning to do so)?

- Different initiatives for different segments, reasons and what types

- Challenges (faced/potential) hindering the motives of these initiatives

- Importance of measuring the effectiveness of these initiatives, techniques (how)

6) What benefits will consumer empowerment give to the economy, banks and consumers?

- Effect on Performance and Customer Relationship Management of banks (how)

7) Prospects

- Compulsion or only the responsibility of regulators/government

- Would compulsion be effective

- Collaborative programs by banks

- Perception on future of consumer empowerment (widespread/why or why not) 